\title{
An Analysis of Morphological and Syntactical Errors on the English Writing of Junior High School Indonesian Students
}

\author{
Hendri Gayo and Pratomo Widodo \\ Yogyakarta State University \\ Yogyakarta, Indonesia
}

\begin{abstract}
Since English has been studied for many years in Indonesia, it is important to recognize some common errors that are produced by the learners in order to help them to improve teaching and learning strategies for the English language. Therefore, this research aims to investigate the errors that occur on students' English writing at the morphological and syntactical levels and the factors that cause these errors. This qualitative descriptive research describes and investigates the errors and their factors. The result of the study shows that, firstly, the types of morphological errors occur in the omission, addition, and misformation which include the derivation, inflection, preposition, article, copula be, personal pronoun, auxiliary, and determiner. Secondly, syntactical errors occur in the omission, addition, misformation, and disordering which include the passive voice, tense, noun phrase, auxiliary, subject-verb agreement, and determiner. The two major sources of errors are the interlingual (first language interference) and intralingual factors.
\end{abstract}

Keywords: morphological errors; syntactical errors; interlingual; intralingual; error analysis.

\section{Introduction}

English is studied in Indonesia as from an early age. Indonesians learn English from elementary school to senior high school. Despite so many years of learning the English language, most Indonesians still have much difficulty in expressing themselves in English and writing good English as well. In order to help the students improve their English language skills, it is important to recognize some language errors that are most commonly made them. Most Indonesians have their local language (jawa, batak, aceh, minang, etc) as their first language (L1) and Bahasa as the second language (L2). This condition makes English a foreign language in Indonesia. 
In order to write good English, several aspects of the language must be taken into consideration namely its morphology, syntax, semantics, and pragmatism (Bauer, 2007). In addition, Richards \& Schmidt (2002) add that language is a human communication system that consists of a structure and arrangement from morpheme to discourse. It can be said that, in mastering the writing, the learners should master the other components, such as morpheme, syntax, etc.

Writing is a skill that is hard to master as many different types of errors can occur during this process. Flynn \& Stainthorp (2006) state that writing is a complex task that requires cognitive skills of learners and the ability to perform different activities simultaneously. Many EFL (English as a Foreign Language) learners encounter writing difficulties and one of the major one is linked to English grammar (Belkhir \& Benyelles, 2017). Cam \& Tran (2017) found that the lack of grammatical knowledge is responsible for students' deficiency in English. It is very important to master English grammar in order to make a good writing.

Observations has been made at the SMP Negeri 9 Yogyakarta and it revealed that many students still make errors in the correct usage of English grammar. Examples are using the singular/plural forms (many building*) of words and noun phrases (body large*). The first error is an error at the morphological level. The sentence omits the use of the morpheme of word plurality. The derivation $-s$ is required in order to form a plural noun to be in concord with the plural determiner many. The second error is the disordering of a noun phrase. The head noun is body and the modifier is large. The position of the head noun must be after the modifier.

Based on these types of observations, an in-depth study was conducted to analyse the different types of errors that EFL students are regularly making. The focus of this study are errors at the morphological and syntactical levels in the rank of morphemes, words, phrases, clauses, and sentences. The type of error includes omission error, addition error, misformation error, and disordering error in the morpheme and syntax elements.

\section{Literature Review}

\section{a. Contrastive Analysis (CA)}

In the middle of the twentieth century, Contrastive Analysis (CA) became the first major theory for applied linguistics dealing with the relationship between two languages. Lado (in Saville-Troike, 2006) proposed a contrastive method to study the different languages. Lado (in Brown, 2007) suggested that if two different languages have similar language components, then it would be easier for learners to learn the target language from the native one. However, if the components were different, then it would be difficult for the learners as their first language interferes with the acquisition of the foreign language.

Ciesielkiewicz \& Marquez (2015) stated that a contrastive analysis was similar tobehaviorism as behavioral linguists claim that habits that are acquired while 
learning native languages are transferred into the acquisition of a target language. Furthermore, Saville-Troike (2006) stated that contrasting the first and the target language results in both positive and negative transfers. A positive transfer occurs when the native language rules can be used in the acquisition of the target language. On the other hand, a negative transfer or interference occurs when the native language rules cannot be used in the acquisition of the target language. Errors can be caused not only by the influence of the first language (interlanguage), but also by the target language itself (intralingual). Rustipa (2011) showed that sometimes even a contrastive analysis done on the native language and the target language cannot predict the cause of the errors.

\section{b. Error Analysis (EA)}

Error analysis (EA) appeared in the 1970s to discuss the errors made by language learners. EA offered an alternative view towards learners' errors compared to contractive analysis (CA). According to error analysis, learners' errors are not only caused by the native language but also by more universal learning strategies (Richards \& Schmidt, 2002). The fact that learners' errors can be observed, analyzed, and clarified to reveal the learners' errors became the basis for EA to investigate the errors. It is in contrast to CA which views that the learners' errors in the target language is the result of interference from their first language (Brown, 2007; Khansir, 2012).

EA replaced CA in the early 1970s because of the following reasons (SavilleTroike, 2006):

a. The errors that were predicted by CA do not always occur in actual learners' errors. Many of learners' errors did not relate to the L1 interference.

b. As the theory of linguistic has changed, the concern for structural linguistic moved from surface-level forms and patterns to fundamental rules.

c. Linguists and psychologists questioned have the assumption of behaviorists who believe that habit formations is a part of language acquisition.

Corder (in Ellis, 1994) as the mover of the analysis of learners' errors refocused the errors from the perspective of the language process and language acquisition. Corder suggested five steps to analyze the learners' errors: sample collection, errors identification, errors description, errors explanation, and errors evaluation.

The first step is collecting sample data for analysis. The researcher may control the data by narrowly specifying the sample that they intend to collect. Some researchers used samples that were collected in periods of weeks, months, or even years in order to determine patterns of error utterances. The second step is the identification of errors. In this step, the researcher identified the errors by comparing the learners' sentences with the corresponding native sentences. Then, the researcher identify which parts of the learners' sentences were different from the natives' sentences.

The third step is a description of the errors. In this step, the researcher describes the errors using the surface strategy taxonomy in order to describe the difference 
between learners' sentences and the corresponding native's sentences. Corder (in Ellis, 1994) classified the errors into three types:

a. Presytematic errors occur when the learners were not conscious of the existence of particular rules in the target language.

b. Systematic errors occur when the learners had the understanding of the rule but the rule was an incorrect one.

c. Postsystematic errors occur when the learners produced errors inconsistently even when they understood the rules.

The fourth step is an explanation of the errors. In this step, the researcher determines the sources of error, in order to find the reasons for the learners' errors. The last step is the evaluation of errors. In this step, the researcher determines which parts of the errors need more explanation or attention. Those five steps are important in order to analyze and understand the learners' errors.

\section{c. Notions of Error}

In the process of language learning, there were some possibilities that the learners might produce errors in the target language. The second and foreign language learner did not always produce errors; even the first language learner often sometimes produce errors. Ellis (1994) stated that not only the second language learners made errors, but also children who learnt their first language as well as native adults.

There are two essential terms that should be distinguished when analyzing errors in the learning of a foreign language. These are errors and mistakes. These two terms are used to relate to the failure of using correct utterances in the target language. Errors occurred when the learners produce errors that were new rules for them, while mistakes are incorrectly applied rules (Krisnawati, 2013). Moreover, Ellis (1994) claimed that errors occur because of lack of knowledge. On the other hand, mistakes occur when learners fail to apply their language skills.

Errors and mistakes can be also distinguished by their corrigibility. James (1998) define errors as instances of language that were not self-corrigible by their writers whereas mistakes can be both intentional or unintentional language deviants and are usually self-corrigible by their writers. This means that the learners cannot correct their own errors, but they can correct their own mistakes. In addition, Tarigan (2011) argued that errors were caused by the learners' incompetence, while mistakes were caused by the learners' performance. It can be concluded that errors occurred because of lack knowledge of the learners towards the target language and occur consistently and systematically.

\section{d. Classification of Errors}

Dulay et al. (1982) categorized language errors into four taxonomies. These were (1) the linguistics category, (2) the surface structure taxonomy, (3) the comparative taxonomy, and (4) the communicative effect taxonomy. This research only uses the surface structure taxonomy. 
The surface structure taxonomy is used to explain the error phenomena. Dulay et al. (1982) wrote that learners might omit necessary items, add unnecessary items, misform the items, or disorder the items. Ellis (1994) also added that the omission indicates the omission of a certain linguistic item that must not appear in a well-formed utterance, addition indicates the addition of a certain linguistic item that must not be appeared in well-formed utterance, misformation indicates the use of an incorrect form of a certain linguistic in the target language utterance, and disordering indicates the incorrect arrangement of a certain linguistic in the target language utterance. Examples of errors in the four categories of surface taxonomy in grammar (morpheme and syntax) are as follows:

Table 1. Examples of Surface Strategy Errors in Morpheme and Syntax Levels

\begin{tabular}{ll}
\hline $\begin{array}{l}\text { Error } \\
\text { Categories }\end{array}$ & Examples \\
\hline Omission & (1) She (is) sleeping. \\
& (2) I go (to) play. \\
\hline Addition & $\begin{array}{l}\text { (1) We didn't went there. } \\
\text { (2) He calleded. }\end{array}$ \\
\hline Misformation & $\begin{array}{l}\text { (1) The dog ated the chicken. } \\
\text { (2) We should studying tonight. }\end{array}$ \\
\hline Disordering & (1) What daddy is doing? \\
& $\begin{array}{l}\text { (2) We don't know why are we } \\
\text { facing these problems. }\end{array}$ \\
\hline (Sources: Ellis, 2003; Dulay, et al., 1982; Margana, 2012)
\end{tabular}

\section{e. Sources of Error}

The two main sources of errors in the learning of a new language are interlingual and intralingual errors (Brown, 2007). Interlingual errors come from interference from the first language. In this context, the first language is Bahasa which is the interferer and English as the target language is the interfered. On the other hand, intralingual errors occur when language learners produce the language using their own creativity. Richard (1974) added that another source of error was developmental errors which occur when learners attempt to build up their own hypotheses of the target language based on their own limited knowledge and experiences. Intralingual errors are the most common type of error. Richard (1974) offered four types of intralingual errors:

\section{i. Overgeneralization}

Overgeneralization occurs when the students cannot use the rule of the target language correctly. Overgeneralization covers errors that are produced by learners when they try to apply a correct rule in an unsuitable situation. An example from Ellis (1994) is as follows:

He cans sing. *

He can sing. 


\section{ii. Ignorance of Rule Restriction}

This source of error occurs when the students cannot use the exception rules. Richard (1974) explained that the ignorance of rule restriction is closely related to overgeneralization. This type of error occurs when a rule is not used in the context where it should have been used. An example from Ellis (1994) is as follows:

He asked me to. *

He asked me to go.

\section{iii. Incomplete Application of the Rule}

This source of error occurs when the students are unable to present some important elements in a word, phrase, or sentence. Richard (1974) pointed out that the incomplete application of rules was the omission of linguistic rules in the production of the target language. An example from Ellis (1994) is as follows:

You like sing?*

Do you like to sing?

\section{iv. False Concept Hypothesis}

This source of error occurs when the students misinterpret the target language rule which results in misusing or misformation of the grammatical elements. Richard (1974) suggested that the misinterpretation of the English rule cause error utterances in English. An example from Ellis (1994) is as follows:

It was happened last Sunday. *

It was last Sunday.

Based on the explanations of the source of different errors above, this research applies the theory of error source as offered by Richard (1974) who categorized the source of errors into two categories: (1) interlingual errors and, (2) intralingual errors.

\section{f. Teaching Writing}

Writing has an important role in qualifying students' achievement in the learning of languages. The achievement in language learning was determined by the students' ability in reading and writing based on the level of education (Indonesian Constitutional No. 19/2005 about National Education Standard article 25 section 3). At the Junior School level, one type of writing that students should master is descriptive writing. Thus, students are expected to be able to write descriptively in English by determining the linguistic system. In this context, the linguistic system that had our attention was grammar, morphology and syntax levels.

A long time is required to master writing skills since other skills such as reading, listening, and grammar are also required. Moreover, Alinsunod (2014) noted that grammar was a main concern in writing competency and in which students commonly make errors. Thus, writing ability was not only the ability in writing paragraphs, but grammatical rules also are crucial concerns for learners. 


\section{Methodology}

\section{a. Subject and Unit of Analysis}

This study is a descriptive qualitative study. It aims to describe the errors that are made by the students at grade IX of SMP Negeri 9 Yogyakarta in their English writing. The participant of this research were 77 students of grade IX who are 15 years old on average. In collecting the data, the students were asked to write a descriptive text about animals, plants, or people consisting of at least 2 paragraphs and not less than 150 words. The students' writing became the subject of the study. The data were analyzed in the rank of morphemes, words, phrases, clauses, and sentences. The data were then categorized into the morphological and syntactical errors.

\section{b. Instruments and Technique of Analysis}

In analyzing the data, this research uses several instruments and techniques of analysis. These are error classification sheets and interview guidelines. The method of data analysis is the referential method (Sudaryanto, 2015). The theory of Burt et al. (1982) is used to categorize and identify the different types of errors, which are, omission, addition, misformation, and disordering of linguistic elements. The interview is used to investigate and clarify the students' errors in order to find the factors that caused the errors. In determining these factors, this research refers to the theory of source of error by Richard (1974).

\section{c. Findings and Discussions}

Based on the analysis of students' writing, this research found many errors. The errors occurred at both the morphological and syntactical levels.

Table 2. Research Findings

\begin{tabular}{|c|c|c|c|c|c|c|c|}
\hline $\begin{array}{l}\text { Linguistic } \\
\text { Level }\end{array}$ & $\begin{array}{l}\text { Kinds of } \\
\text { Error }\end{array}$ & Omit & Add & $\begin{array}{l}\text { Mis- } \\
\text { Form }\end{array}$ & $\begin{array}{l}\text { Mis- } \\
\text { Order }\end{array}$ & Total & Percentage \\
\hline \multirow[t]{8}{*}{ Morpheme } & Inflection & 27 & 13 & 2 & & 42 & $14.19 \%$ \\
\hline & Derivation & 18 & 3 & 7 & & 28 & $9.46 \%$ \\
\hline & Preposition & 14 & 10 & 18 & & 42 & $14.19 \%$ \\
\hline & Article & 27 & 7 & 5 & & 39 & $13.18 \%$ \\
\hline & Copula Be & 27 & 7 & 10 & & 44 & $14.86 \%$ \\
\hline & Pronoun & 7 & 5 & 15 & & 23 & $7.77 \%$ \\
\hline & Auxiliary & 1 & 1 & 12 & & 14 & $5.06 \%$ \\
\hline & $\begin{array}{l}\text { Demonstrative } \\
\text { Determiner }\end{array}$ & 1 & & & & 1 & $0.34 \%$ \\
\hline \multirow[t]{5}{*}{ Syntax } & Passive Voice & & & 9 & & 9 & $3.04 \%$ \\
\hline & Tense & & & 5 & & 5 & $1.69 \%$ \\
\hline & Noun Phrase & & & & 18 & 18 & $6.08 \%$ \\
\hline & Auxiliary & & & & 1 & & $0.34 \%$ \\
\hline & $\begin{array}{l}\text { Subject-Verb } \\
\text { Agreement }\end{array}$ & 4 & & 24 & & 28 & $9.46 \%$ \\
\hline
\end{tabular}




\begin{tabular}{ccccccc}
\hline $\begin{array}{c}\text { Demonstrative } \\
\text { Determiner }\end{array}$ & & & 2 & & 2 & $0.66 \%$ \\
\hline Total & 113 & 43 & 109 & 19 & $\mathbf{2 9 6}$ & $\mathbf{1 0 0 \%}$ \\
\hline Percentage & $\mathbf{4 3 . 1 9 \%}$ & $\mathbf{1 4 . 2 9 \%}$ & $\mathbf{3 6 . 2 1 \%}$ & $\mathbf{6 . 3 1 \%}$ & $\mathbf{1 0 0 \%}$ & $\mathbf{1 0 0 \%}$ \\
\hline
\end{tabular}

\section{Morphological and Syntactical Errors}

Table 2 shows that there are some errors at both morphological and syntactical levels. The errors at the morphological level includes inflection, derivation, preposition, article, copula be, personal pronoun, auxiliary verb, and demonstrative determiner. The highest number of errors occurred in the use of the copula be with a percentage of $14.86 \%$. The lowest number of errors occur in using the demonstrative determiner with a percentage of only $0.36 \%$.

The error at the syntactical level includes passive voice, tense, noun phrase, auxiliary verb, subject-verb agreement, and demonstrative determiner. The largest number of errors occurred when using the subject-verb agreement with a percentage of $9.46 \%$. The lowest number of errors occurred when using the auxiliary verb with a percentage of only $0.34 \%$.

i. Omission

An omission is an error that refers to omitting English linguistic features from a sentence. Table 3 shows examples of such errors.

Table 3. Omission at Morphological and Syntactical Levels

\begin{tabular}{|c|c|c|}
\hline $\begin{array}{l}\text { Levels of } \\
\text { Linguistic }\end{array}$ & $\begin{array}{l}\text { Kinds of } \\
\text { Error }\end{array}$ & Errors \\
\hline \multirow[t]{8}{*}{ Morpheme } & Inflection & $\begin{array}{l}\text { (1) Many cockroach are live with human habit. } \\
\text { (2) Banana is a monkey favourite food. }\end{array}$ \\
\hline & Derivation & $\begin{array}{l}\text { (1) Ants live together by form colonies. } \\
\text { (2) They have antenna on their head as a balance. }\end{array}$ \\
\hline & Preposition & $\begin{array}{l}\text { (1) They usually breed in November } \varnothing \text { April. } \\
\text { (2) There are two river field. }\end{array}$ \\
\hline & Article & $\begin{array}{l}\text { (1) I live in } \varnothing \text { village. } \\
\text { (2) Pitcher plants have } \varnothing \text { most mysterious leaves. }\end{array}$ \\
\hline & Copula be & $\begin{array}{l}\text { (1) Sparrow } \varnothing \text { ready to marry at the age of } 17 \\
\text { months. } \\
\text { (2) I Ø very happy live in village. }\end{array}$ \\
\hline & Personal & (1) Cactus doesn't have branch like other \\
\hline & Pronoun & $\begin{array}{l}\text { general tree, } \varnothing \text { only has body. } \\
\text { (2) } \varnothing \text { Can be found easily at grassfield or Savana. }\end{array}$ \\
\hline & Auxiliary & (1) Hen $\varnothing$ small size. \\
\hline \multirow[t]{2}{*}{ Syntax } & $\begin{array}{l}\text { Subject-Verb } \\
\text { Agreement }\end{array}$ & $\begin{array}{l}\text { (1) Butterfly mostly } \varnothing \text { from Amazon jungle. } \\
\text { (2) In the Malioboro, so crowded in the afternoon. }\end{array}$ \\
\hline & $\begin{array}{l}\text { Demonstrative } \\
\text { Determiner }\end{array}$ & (1) In the world $\varnothing$ about 20000 species of butterfly. \\
\hline
\end{tabular}


Table 3 shows that many errors in students' English writings occur at the morphological and syntactical levels. The errors in morphological level include (1) inflection; omission of inflection -es and -'s, (2) derivation; omission of inflection -ing and -er, (3) preposition; omission of preposition to and in, (4) article; omission of article the and the, (5) copula be; omission of be is and am, (6) personal pronoun; omission of personal pronoun it and it, and (7) auxiliary; omission of auxiliary has. In addition, the errors at the syntactical level occur (1) in the omission of subject-verb agreement comes and (2) demonstrative determiner there are.

ii. Addition

Addition refers to the presence of an extra linguistic element in English utterances. The additions of such elements result in errors in the language. Examples of such errors are shown in Table 4. Addition errors only occur at the morphological level. They do not occur at the syntactical level.

Table 4. Addition Errors at the Morphological Level

\begin{tabular}{|c|c|c|}
\hline $\begin{array}{l}\text { Level of } \\
\text { Linguistic }\end{array}$ & $\begin{array}{l}\text { Kinds of } \\
\text { Error }\end{array}$ & Errors \\
\hline \multirow[t]{7}{*}{ Morpheme } & Inflection & $\begin{array}{l}\text { (1) Some of them can jump to } 30 \text { feets in } \\
\text { the air. } \\
\text { (2) Cockroach is } a \text { insects. }\end{array}$ \\
\hline & Derivation & $\begin{array}{l}\text { (1) A rose is a woody perennial } \\
\text { flowering of the genus Rosa in the } \\
\text { family Rosaceae. } \\
\text { (2) Many people use bus for go to } \\
\text { official. }\end{array}$ \\
\hline & Preposition & $\begin{array}{l}\text { (1) It's located in near big city. } \\
\text { (2) Chicken is easy to find in anywhere. }\end{array}$ \\
\hline & Copula be & $\begin{array}{l}\text { (1) Many cockroach are live with human } \\
\text { habit. } \\
\text { (2) There are many big buildings are } \\
\text { there. }\end{array}$ \\
\hline & $\begin{array}{l}\text { Personal } \\
\text { Pronoun }\end{array}$ & $\begin{array}{l}\text { (1) There are many trees in the my } \\
\text { village. } \\
\text { (2) Coconut tree it is often called tree of } \\
\text { live. }\end{array}$ \\
\hline & Article & $\begin{array}{l}\text { (1) Cats are } a \text { mammals of the Family } \\
\text { Felidae. } \\
\text { (2) The } a \text { church is between the mosque } \\
\text { and the bank. }\end{array}$ \\
\hline & Auxiliary & $\begin{array}{l}\text { (1) Cats have have flexible bodies and } \\
\text { teeth. }\end{array}$ \\
\hline
\end{tabular}

Table 4 shows that students produce some errors at the level of morpheme in their English writing. The students add linguistic features that result in error utterances in English. The errors of addition include (1) inflection; addition of inflection $-s$, (2) derivation; addition of derivation -ing and -al, (3) preposition; addition of preposition near and in, (4) copula be; addition of are and are, (5) 
personal pronoun; addition of personal pronoun my and it, (6) article; addition of article $a$, (7) auxiliary; addition of auxiliary verb have.

iii. Misformation

Misformation refers to the misuse of appropriate linguistic elements. Misformation also results in erroneous utterances in English. Errors in the misformation category at both the morphological and syntactical levels. Examples of such errors are shown in Table 5.

Table 5. Misformation at the Morphological and Syntactical Levels

\begin{tabular}{|c|c|c|}
\hline $\begin{array}{l}\text { Levels of } \\
\text { Linguistic }\end{array}$ & $\begin{array}{l}\text { Kinds of } \\
\text { Error }\end{array}$ & Errors \\
\hline \multirow[t]{8}{*}{ Morpheme } & Inflection & $\begin{array}{l}\text { (1) It has some pinnate leafs. } \\
\text { (2) My town is the most busy town. }\end{array}$ \\
\hline & Derivation & $\begin{array}{l}\text { (1) Many people busy working in here. } \\
\text { (2) Dolphin can be very entertainment. }\end{array}$ \\
\hline & Preposition & $\begin{array}{l}\text { (1) Not only to communication, handphone or } \\
\text { smartphone has other function. } \\
\text { (2) Some of them can jump to } 30 \text { feets in the air. }\end{array}$ \\
\hline & Article & $\begin{array}{l}\text { (3) Our town is a old town. } \\
\text { (4) Elephant is a largest mammal on the land. }\end{array}$ \\
\hline & Copula be & $\begin{array}{l}\text { (1) Now, three species of the tiger is in danger } \\
\text { of extinction. } \\
\text { (2) Snake are also dangerous. }\end{array}$ \\
\hline & $\begin{array}{l}\text { Personal } \\
\text { Pronoun }\end{array}$ & $\begin{array}{l}\text { (1) Cactus has leaves like hair but it is spines. } \\
\text { (2) Sparrow using it beak to eat. }\end{array}$ \\
\hline & Auxiliary & $\begin{array}{l}\text { (1) This fish have a beautiful fins and colorful } \\
\text { tails. } \\
\text { (2) My father have a big farm. }\end{array}$ \\
\hline & $\begin{array}{l}\text { Demonstrative } \\
\text { Determiner }\end{array}$ & $\begin{array}{l}\text { (1) The majority of there beetles eaten some little } \\
\text { animal like an aphids. } \\
\text { (2) This mammals lives in a group. }\end{array}$ \\
\hline \multirow[t]{3}{*}{ Syntax } & Passive Voice & $\begin{array}{l}\text { (1) They are breed by sprouting. } \\
\text { (2) Its structure } k \text { now as pitfall traps. }\end{array}$ \\
\hline & Tense & $\begin{array}{l}\text { (1) I am living in Junikarta for } 20 \text { years. } \\
\text { (2) Some butterfly become rare because many } \\
\text { people has been hunt for collection. }\end{array}$ \\
\hline & $\begin{array}{l}\text { Subject-Verb } \\
\text { Agreement }\end{array}$ & $\begin{array}{l}\text { (1) They works from Monday to Friday. } \\
\text { (2) They are the big cat which lives on earth. }\end{array}$ \\
\hline
\end{tabular}

Errors at the morphological levels include (1) inflection; addition of inflection -s and most, (2) derivation; misforms of derivation -ing and ment, (3) article; misformation of article $a$, (4) copula be; misformation of be is and are, (5) personal pronoun; misformation of it, (6) auxiliary; misformation of have, and (7) demonstrative determiner; misformation of the determiner there. 
The errors at the syntactical level include (1) passive voice; misformation of verb and be for passive voice, (2) tense; misformation of verb tense, (3) subject-verb agreement; misformation of the concord between subject and verb.

iv. Disordering

Disordering refers to word order of the phrase or sentence in English utterances. Examples of such errors are found in Table 6.

Table 6. Disordering at the Syntactical Level

\begin{tabular}{|c|c|c|}
\hline $\begin{array}{l}\text { Level of } \\
\text { Linguistic }\end{array}$ & $\begin{array}{l}\text { Kinds of } \\
\text { Error }\end{array}$ & Errors \\
\hline \multirow[t]{3}{*}{ Syntax } & Noun & Cactus has body large. \\
\hline & Phrase & $\begin{array}{l}\text { They have suction mouth nectar } \\
\text { flowers. }\end{array}$ \\
\hline & Auxiliary & Turtles not have teeth. \\
\hline
\end{tabular}

Disordering errors include (1) noun phrase; disordering of word order, and (2) auxiliary; disordering of the negation form.

\section{Sources of Error}

Based on the data analysis, it was found that the two major sources of error in students' English writing are interlingual and intralingual errors.

\section{a. Interlingual Error}

The first possible cause of interlingual errors in the target language utterance are interferences caused by the first language. The Bahasa influences the utterances in English writings, especially in the case of using prepositions and noun phrases. The different rules between Bahasa and English make the utterances in English ungrammatical. The literal word-to-word translation method employed by the students also contributes to such types of errors. Table 7 shows some examples of interlingual errors.

Table 7. Examples of Interlingual Errors in Students' English Writing

\begin{tabular}{lll}
\hline $\begin{array}{l}\text { Aspects of } \\
\text { Errors }\end{array}$ & Errors & Bahasa \\
\hline Preposition & $\begin{array}{l}\text { (1) The two rabbits in near the } \\
\text { river. } \\
\text { (2) It is located in behind the } \\
\text { Konoha city. }\end{array}$ & $\begin{array}{c}\text { (1) Kedua kelinci di dekat sungai. } \\
\text { Konoha. }\end{array}$ \\
\hline $\begin{array}{lll}\text { Noun } \\
\text { Phrase }\end{array}$ & $\begin{array}{ll}\text { (1) Cactus has body big. } \\
\text { (2) They eat the seed grain. }\end{array}$ & $\begin{array}{l}\text { (1) Kaktus memiliki tubuh besar. } \\
\text { (2) Mereka memakan biji padi. }\end{array}$ \\
\hline Auxiliary & (1) Turtles not have teeth. & (1) Kura-kura tidak memiliki gigi. \\
\hline
\end{tabular}


Most of the interlingual errors are caused by the inappropriate use of the wordto-word translation technique. The students did not consider the proper rules for the creation of prepositional and noun phrases. The English negation rule was also not used properly by the students.

\section{b. Intralingual Errors}

Intralingual errors are the result of students' creativity to create utterances. Table 8 shows examples of such errors.

Table 8. Examples of Intralingual Errors in Students' English Writing

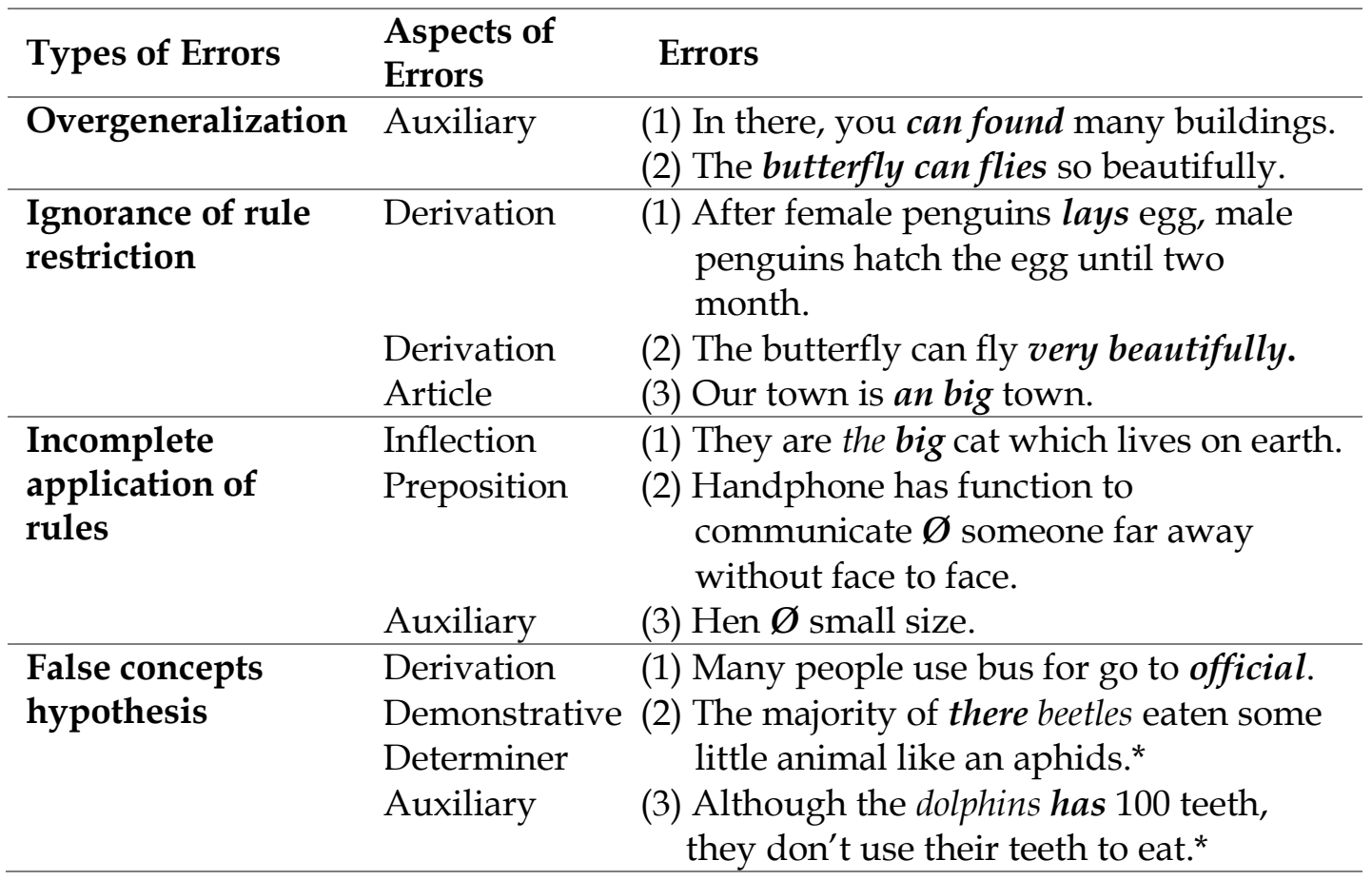

Intralingual errors occur in the overgeneralization of utterances, the ignorance of rule restrictions, the incomplete application of language rules, and the false concept of hypothesis.

\section{Conclusions}

Based on the findings and discussion above, two conclusions can be drawn from this study. Firstly, the errors that are found in students' English writing occur at both the morphological and syntactical levels. The morphological includes derivation morpheme, inflection morpheme, preposition, article, copula be, personal pronoun, auxiliary verb, and demonstrative determiner. While the syntactical level includes tense, passive voice, noun phrase, auxiliary, subjectverb agreement, and demonstrative determiner. The morphological and syntactical errors occur in the types of omission, addition, misformation, and disordering. Secondly, interlingual and intralingual factors contribute to such errors. These findings can be used for teaching and learning of the English language. The teacher can predict the errors that will be produced by the students, especially for Indonesian English Learners (ELLs) in their earlier study and they can therefore take appropriate measures to reduce such types of errors. 
Indonesian students and all those learning English as a second language can also use these findings to learn correct English. As English becomes the need for this new era, the students should be able to use correct English grammar in order to deliver their messages correctly without any errors and misinterpretations.

\section{References}

Alinsunod, J. (2014). A study of common writing errors of engineering students: a basis for curriculum development. European Journal of English Language and Literature Studies, 2(3), 7-15.

Belkhir, A. \& Benyelles, R. (2017). Identifying EFL learners essay writing difficulties and sources: a move towards solution the case of second year EFL learners at Tlemcen University. International Journal of Learning, Teaching, and Educational Research, 16(6), 80-88.

Brown, H. D. (2007). Principles of language learning \& teaching (4th ed). New York: Pearson Education.

Bauer, L. (2007). The linguistics student's handbook. Edinburgh: Edinburgh University Press.

Ciesielkiewicz, M., \& Marquez, E. (2015). Error analysis and its relevance to teaching ESL composition. International Journal of Linguistics, 7(5), 1-15.

Dulay, H., Burt, M., \& Krashen, S. (1982). Language two. Oxford: Oxford University Press.

Ellis, R. (1994). The study of second language acquisition. Oxford: Oxford University Press.

Flynn, N., \& Stainhorp, R. (2006). The learning and teaching of reading and writing. West Sussex: Wiley and Sons Ltd.

James, C. (1998). Errors in language learning and use. London: Longman.

Khansir, A. A. (2012). Error analysis and second language acquisition. Theory and Practice in Language Studies, 2(5), 1027-1032.

Krisnawati, E. (2013). Error or mistake? Incorrectness in students' answers in a subjectmatter examination. International Journal of Language Learning and Applied Linguistics World, 4, 1-16.

Cam, L. \& Tran, T. M. T. (2017). An evaluation of using games in teaching English grammar for first year English-majored students at Dong Nai Technology University. International Journal of Learning, Teaching, and Educational Research, 16(7), 55-71.

Margana, M. (2012). An error analysis on thesis draft writing performed by students of English education study program of faculty of languages and arts of State University of Yogyakarta. Proceedings of the $2^{\text {nd }}$ UAD TEFL International Conference, 134-145.

Richard, J. (Ed). (1974). Error analysis. London: Longman.

Richards, J. C. \& Schmidt, R. (2002). Longman dictionary of language teaching and applied linguistics. Great Britain: Pearson Education.

Rustipa, K. (2011). Contrastive analysis, error analysis, interlanguage, and the implication to language teaching. Ragam Jurnal Pengembangan Humaniora [Journal of Humanity Development], 11(1), 1-13.

Saville-Troike, M. (2006). Introducing second language acquisition. Cambridge: Cambridge University Press.

Sudaryanto, D. P. (2015). Metode dan aneka teknik analisis Bahasa [Method and technique of language study]. Yogyakarta: Sanata Dharma University Press.

Tarigan, H. G. (2011). Pengajaran analisis kesalahan berbahasa [Teaching of language error analysis]. Bandung: Aksar. 